\title{
The Effects of Early Childhood Teachers' Backgrounds and Competence for Building Educational Community on Parent-Teacher Cooperation
}

\author{
Kai Sook, Chung1, a, Gab Jung, Yoon², b \\ ${ }^{1}$ Professor of Pusan National University, Pusan, South Korea \\ ${ }^{2}$ Associate Professor of Daegu Haany University, Gyeongsan, South Korea \\ akschung@pusan.ac.kr, bgyoon3@dhu.ac.kr
}

\begin{abstract}
Keywords: Early Childhood Teacher, Competence for Building Educational Community, ParentTeacher Cooperation
\end{abstract}

\begin{abstract}
This study is to examine the relative influence of early childhood teacher's backgrounds and competence for building educational community on cooperation with parents. The sample of the research consisted of 638 early childhood teachers and they filled up a questionnaire. The collected data were analyzed by SPSS 20.0 program. The results are as follows: 1) Teacher's age, career, academic background and all sub-variables (psychological competence for partnership and social competence for sharing key values) of competence for building educational community were significantly related to all sub-variables (information sharing, information seek, and adult relations) of parent-teacher cooperation. 2) Teacher's age, career, academic background and competence for building educational community predicted parent-teacher cooperation and 'academic background' and 'psychological competence for partnership' were represented as the significant variables. This study suggests that teacher's psychological empowerment for partnership with parent toward building educational community is crucial for developing successful parent-teacher cooperation.
\end{abstract}

\section{Introduction.}

Effective cooperation between schools and families is a significant factor for not only improving the children's academic and social-emotional development but also the effectiveness of schools $[1,2,3]$. So, teacher education experts have been highlighted that developing productive relationships with parents is part of a teacher's professional role $[4,5,6]$; however, creating parent-teacher cooperation is much more complex, difficult and dynamic than the rhetoric of philosophy, policy and practice suggests [7]. In fact, most of early childhood teachers mention difficulties and challenges when it comes to building cooperative relationships with parents [8].

Meanwhile, recently literatures suggest that building educational community could be one of the solution for parent-teacher misunderstanding and mistrust [9, 10]. Still, many studies have been figured out effects early childhood teacher's cooperation with parents on children's peer relationships, adjustment, and teacher-child interaction [11, 12, 13] but little effort to focused on teacher's competence for building educational community on parent-teacher cooperation.

\section{Purpose.}

The focus of this study is to examine the relative influence of early childhood teacher's backgrounds and competence for building educational community on cooperation with parents. Also, the study intend to teacher's empowerment and educational implications for developing parent-teacher cooperation. 


\section{Method.}

The sample of the research consisted of 638 early childhood teachers selected according to cluster sampling method in Southeast area, South Korea. The mean age was 32.21 years $(\mathrm{SD}=7.98$, range $=19-60)$ and they had a mean of 5.70 years $(\mathrm{SD}=4.18)$ of teaching experience. Their academic backgrounds consisted of 42 high school, 247 college, 319 university, 30 graduate school. They filled up a questionnaire and the collected data were analyzed by descriptive statistics, t-test, Pearson product-moment correlation analysis and multiple regression analysis.

\section{Measures}

The survey contained items on participants' demographic information, teacher's competence for building educational community and parent-teacher cooperation scales. Early Childhood Teacher's Competence for Building Educational Community was measured with the 42-item which consists of items on two dimensions: psychological competence for partnership and social competence for sharing key values. Each item consists of a short statement and respondents are required to rate the degree to which they agree with the statements on a 6-point scale ranging from 1 (extremely disagree) to 6 (extremely agree). In this study, the Cronbach's $\alpha$ coefficients was .97 And Parent-Teacher Cooperation was measured with 14-items derived from Lim \& Ahn (2011), consisted of four items (sharing information, seeking information, adult relations). The measure has a 5-point rating scale, with higher values representing more successful cooperation with parents. The Cronbach's acoefficient for this scale was .91 in this study.

\section{Results.}

\subsection{Correlation between teacher's backgrounds, competence for building educational community and parent-teacher cooperation}

The correlation results in Table 1 showed that teacher's age, career, academic background and all subvariables (psychological competence for partnerships and social competence for sharing key values) of competence for building educational community were significantly related to all sub-variables (sharing information, seeking information, and adult relations) of parent-teacher cooperation.

Table 1. correlations of the study variables

\begin{tabular}{ccccc}
\hline & $\begin{array}{c}\text { Sharing } \\
\text { Information }\end{array}$ & $\begin{array}{c}\text { Seeking } \\
\text { Information }\end{array}$ & $\begin{array}{c}\text { Adult } \\
\text { Relations }\end{array}$ & $\begin{array}{c}\text { Parent-Teacher } \\
\text { Cooperation }\end{array}$ \\
\hline Career & $0.23^{* * *}$ & $0.10^{* *}$ & $0.14^{* * *}$ & $0.18^{* * * *}$ \\
\hline Age & $0.15^{* * *}$ & 0.06 & $0.09 *$ & $0.12^{* *}$ \\
\hline $\begin{array}{c}\text { Academic } \\
\text { background }\end{array}$ & $0.11^{* *}$ & $0.09 *$ & $0.09 *$ & $0.11^{* *}$ \\
\hline $\begin{array}{c}\text { Psychological competence } \\
\text { for partnerships }\end{array}$ & $0.41^{* * *}$ & $0.35^{* * *}$ & $0.39 * * *$ & $0.44^{* * *}$ \\
\hline $\begin{array}{c}\text { Social competence for } \\
\text { sharing key values }\end{array}$ & $0.36^{* * *}$ & $0.29 * * *$ & $0.32^{* * *}$ & $0.37 * * *$ \\
\hline
\end{tabular}

$* p<.05, * * p<.01, * * * p<.001$

5.2 Effects of teacher's backgrounds, competence for building educational community on parent-teacher cooperation

In the regression results in Table 2, teacher's age, career, academic background and competence for building educational community predicted parent-teacher cooperation and 'academic background' and 'psychological competence for partnership' were represented as the significant variables. 
Table 2. multiple regression of factors associated with parent-teacher cooperation

\begin{tabular}{|c|c|c|c|c|c|c|c|}
\hline & & B & S.E & $\beta$ & $\mathrm{t}$ & $\mathrm{R} 2$ & $\mathrm{~F}$ \\
\hline \multirow{6}{*}{$\begin{array}{l}\text { Sharing } \\
\text { Information }\end{array}$} & & 1.67 & 0.21 & & $7.82 * * *$ & \multirow{6}{*}{0.21} & \multirow{6}{*}{$30.62 * * *$} \\
\hline & Career & 0.01 & 0.01 & 0.09 & 1.88 & & \\
\hline & Age & 0.01 & 0.00 & 0.08 & 1.74 & & \\
\hline & $\mathrm{AB}$ & 0.12 & 0.03 & 0.15 & $3.97 * * *$ & & \\
\hline & PCP & 0.27 & 0.06 & 0.25 & $4.40 * * *$ & & \\
\hline & SCSKV & 0.13 & 0.05 & 0.13 & $2.34 *$ & & \\
\hline \multirow{5}{*}{$\begin{array}{l}\text { Seeking } \\
\text { Information }\end{array}$} & & 2.29 & 0.21 & & $10.89 * * *$ & \multirow{5}{*}{0.12} & \multirow{5}{*}{$21.65 * * *$} \\
\hline & Career & 0.00 & 0.01 & 0.01 & 0.34 & & \\
\hline & Age & 0.07 & 0.03 & 0.09 & $2.34 * *$ & & \\
\hline & PCP & 0.32 & 0.07 & 0.28 & $4.75 * * *$ & & \\
\hline & SCSKV & 0.06 & 0.06 & 0.06 & 1.01 & & \\
\hline \multirow{6}{*}{$\begin{array}{l}\text { Adult } \\
\text { Relations }\end{array}$} & & 1.96 & 0.23 & & $8.39 * * *$ & \multirow{6}{*}{0.16} & \multirow{6}{*}{$21.42 * * *$} \\
\hline & Career & 0.00 & 0.01 & 0.03 & 0.69 & & \\
\hline & Age & 0.00 & 0.00 & 0.03 & 0.67 & & \\
\hline & $\mathrm{AB}$ & 0.07 & 0.03 & 0.08 & $2.08^{*}$ & & \\
\hline & PCP & 0.35 & 0.07 & 0.31 & $5.19 * * *$ & & \\
\hline & SCSKV & 0.07 & 0.06 & 0.07 & 1.14 & & \\
\hline \multirow{6}{*}{$\begin{array}{l}\text { Parent- } \\
\text { Teacher } \\
\text { Cooperation }\end{array}$} & & 1.90 & 0.20 & & $9.72 * * *$ & \multirow{6}{*}{0.21} & \multirow{6}{*}{$31.19 * * *$} \\
\hline & Career & 0.01 & 0.01 & 0.05 & 1.00 & & \\
\hline & Age & 0.00 & 0.00 & 0.06 & 1.23 & & \\
\hline & $\mathrm{AB}$ & 0.09 & 0.03 & 0.12 & $3.25^{* *}$ & & \\
\hline & PCP & 0.31 & 0.06 & 0.32 & $5.51 * * *$ & & \\
\hline & SCSKV & 0.10 & 0.05 & 0.11 & 1.92 & & \\
\hline
\end{tabular}

${ }^{*} p<.05, * * p<.01, * * * p<.001$

(AB: Academic Background/ PCP: Psychological Competence for Partnerships/ SCSKV: Social Competence for Sharing Key Values)

\section{Conclusions.}

The present study showed early childhood teacher's academic background and psychological competence for partnership toward building educational community are important factor for parentteacher cooperation. In another words, it means that teachers with higher education and psychological competence for partnerships with parents could develop effective and successful cooperation with parents. Therefore, this study suggests that teacher's psychological empowerment for partnership with parents toward building educational community is crucial for developing successful parentteacher cooperation.

\section{Acknowledgements}

This work was financially supported by the National Research Foundation of Korea. And this is result from SSK(Social Sciences Korea) research project of NRF.

\section{References}

[1]. Epstein, J. L. (2011). School, family, and community partnerships: Preparing educators and improving schools $\left(2^{\text {nd }}\right.$ ed.). Boulder, CO: Westview Press. 
[2]. Webster-Stratton, C., Reid, J., \& Hammond, M. (2001). Preventing conduct problems, promoting social competence: A parent and teacher training partnership in head start. Journal of Clinical Child Psychology, 30(3), 283-302.

[3]. Mapp, S. C. (2002). A framework for family visiting for children in long-term foster care. Families in Society, 83(2), 175-182.

[4]. Hirsto, L. (2010). Strategies in home and school collaboration among early education teachers. Scandinavian Journal of Educational Research, 54(2), 99-108.

[5]. Epstein, J. L. \& Sanders, M. G. (2006). Prospects for change: Preparing educators for schoo, family, and community partnerships. Peabody Journal of Education, 81(1), 81-120.

[6]. Ratcliff, N. \& Hunt, G. (2009). Building teacher-family partnerships: The role of teacher preparation programs. Education, 129(3), 495-505.

[7]. Hedges, H. \& Lee, D. (2010). 'I understood the complexity within diversity': preparation for partnership with families in early childhood settings. Asia-Pacific Journal of Teacher Education, 38(4), 257-272.

[8]. Chung, K-S., Yoon, G-J., \& Son, H-H. (2015). Analysis of the subjective attitudes of early childhood teachers on parent-teacher partnerships: The application of Q-method. Early Childhood Education Research \& Review, 19(2), 243-272.

[9]. Chung, K-S., Yoon, G-J., Kyun, J-Y., cha, J-R., Park, H-K. (2016). The figure and practical tasks of "warm" early childhood educational community for recovering healthiness of early childhood education. Korean Journal of Early Childhood Education, 36(1), 153-182.

[10]. Lee, S. S. \& Kim. E. J. (2016). Exploring the competencies of the Ddaddethan educational community. Journal of Educational Studies, 47(2), 105-132.

[11]. Kang, K. H. (2013). The effect of parent-infant attachment, parent-teacher partnership, and teacher-infant relationship on infants' adaptation in child care centers. Kyunghee University master's thesis.

[12]. Do, K-E. \& Lee, S-J. (2016). The influences of trust and cooperation between the teachers and mothers of young children on the child-teacher relations in child care centers. Journal of Parent Education, 8(2), 167-183.

[13]. Kim, Y. H. \& Park, J. H. (2014). The relationship between teacher-child interaction and peer play behaviors among young children: the moderating role of parent-teacher partnerships. Korean Journal of Early Childhood Education, 34(3), 135-152. 